\title{
How to increase your chances of publishing
}

\author{
David L. Hopkins ${ }^{1 *}$
}

A b s tra c t: Every scientist is required to publish their work, a process that gives creditability to their findings and provides a platform for the real-life application of the findings. Although the conduct of experiments is the core of much scientific work, there is sadly a percentage of studies that are based on flawed designs or written by authors who do not understand how to robustly analyse the data they generate. The consequence is that when they attempt to publish in reputable journals, they often have their papers rejected. In other cases, authors may fail to consider the scope of a target journal, their papers are poorly written, or not formatted according to the journal's guidelines. These again lead to rejection. Overall, this presents a large cost to the research and development (R\&D) sector, as some work will never get published, and therefore, the investment has yielded zero returns. In addition, the time spent revising papers adds to the overall cost of undertaking $R \& D$. In many cases, better training can help to reduce these costs and significantly improve the scientific output of scientists. This paper is designed to help authors to improve their success rate when attempting to publish.

Keywords: scientific journal, publishing, chance.

\section{Introduction}

The publication of research outcomes in the scientific literature is the approach that has been adopted by the community to give creditability to the reported findings. Given that public money is often expended to generate the findings, it is imperative that the resulting publications are of high quality and based on well designed and properly executed experiments. Having held editorial roles with three journals and in the light of several years as the Chief Editor of the international journal Meat Science, I have observed that there is a real need for scientists and their students to be better informed and taught about how to achieve the goal of scientific publication. Administrators often do not place enough emphasis on scientific publication and instead want the quick adoption of unpublished outcomes. This is a flawed approach. The process of publication gives confirmation that the findings have been independently scrutinized by experienced people (peer-reviewed) and they are ready to be translated to adopters. This point withstanding, scientists have a responsibility to produce robust findings and to produce high quality papers, yet this often does not occur and as a consequence journal editors see many papers that are rejected, with levels often higher than $75 \%$ for good quality journals. It is worth mentioning here that often sub-standard papers will be published, but in the long term, this practice reflects on the accepting journal. Publication for the sake of publication should never be the objective of a journal. This paper is designed to outline how researchers can be successful in publishing scientific papers and is based on my extensive experience as a reviewer, author, and editor.

\section{Background}

There are about 10,000 journal publishers globally, of which approximately 5,000 are found in the Scopus database (https://www.scopus.com/). These currently publish more than 23,000 peer-reviewed journals, a number which is growing and now includes an increasing number of Open access journals. Collectively, these will publish more than 3 million papers per year. If we focus on the 30 Food Science journals that were published by Elsevier, in 2020 there were more than 58,000 papers submitted to these journals, and these had an overall acceptance (success) rate of $21 \%$. This immediately should raise concerns. It suggests that a significant amount of research will never be published or available in the public domain. The

\footnotetext{
*Paper was announced as plenary lecture on $61^{\text {st }}$ International meat industry conference - meatcon2021 held on Zlatibor mountain on September 26-29th 2021.
}

${ }^{1}$ NSW Department of Primary Industries, Centre for Red Meat and Sheep Development, PO Box 129, Cowra, NSW 2794, Australia

*Corresponding author: David Hopkins, dkhopkins6@gmail.com 
percentage of submitted and subsequently unpublished manuscripts is in the order of $20 \%$ for Meat Science, given rejected papers are often subsequently published in other journals, but with extra cost reflected in salaries and time to revise those papers!

\section{Problem areas}

One of the most important factors that is often not commonly understood by scientists is the requirement for robust experimental designs. Repeatedly, as an editor, I deal with papers based on flawed designs, the most common being the lack of replication. It is blatantly obvious that many scientists do not understand this requirement and as a result, this is often reflected in the papers of their students. The critical factor is to understand what is an "experimental unit", and thus, what is a replicate. A true replicate is the smallest unit to which an experimental manipulation is independently applied. For example, if you make a batch of "novel" sausage mixture and divide this up into sub-units to analyze or apply further treatments to, then to ensure you have replication you need to make further independent batches and repeat the process as the batch is the level of replication. The sub-units are not true replicates, but pseudo replicates. For a feeding experiment, the same consideration needs to be applied. In this case the best replication is to independently feed each animal so that the individual animal is the replicate. You could also have multiple pens of animals group fed the same diet and achieve replication at this level, but it is less powerful as you end up comparing only the mean data of the pen. To illustrate this point, 4 pens per feeding treatment would produce 4 means for comparison (and require a lot more feed than if you had, for example, 3 animals per pen), whereas to feed 4 individual animals would give the same number of replicates. It is imperative that the design of experiments is solidly constructed and authors are encouraged to create the design and then use "dummy" data to ensure the data can be analyzed before they start any experiments. This includes undertaking power tests to ensure there are enough replicates to detect any likely significant differences.

A related issue is the lack of understanding about how to analyze data and which type of analysis and models to apply. If we consider the example of the sausage mixture experiment, then this would require a model that had a fixed term for the treatment and a random term for the replication. This is a mixed model as it contains a fixed and random term. If say a storage component was part of the design, then it would be fitted as an additional fixed term and its interaction with the treatment effect would need to be included. Often scientists omit the fixed term interactions in the model and thus the interpretation of the results is incorrect. Another common issue is the failure to provide the model for the analysis of sensory data, which should account for additional sources of variation, such as the effects of session or panelist. Feedback to authors is often provided with a suitable reference to consult (e.g. Biffin et al, 2020).

The misuse of correlation analysis is often encountered, and some authors fail to understand that this metric only indicates collinearity (association) and NOT causation. In this respect, correlations need to be used carefully. For instance, if you undertake an experiment, create different treatments, pool the data, and then look at their correlations, you can get a false idea of the strength of the association because of the variance due to treatments. In terms of linear modelling, the following reference provides some guidance on how to approach this analysis (Starkey et al. 2017), noting that in both cases experienced biometricians are authors on these papers. Scientists are well advised to develop working relationships with such people to ensure their designs are robust along with the analysis. Fewer papers would be rejected if this policy was adopted and assurance made to ensure that replication is properly applied.

\section{What do editors look for?}

When assessing a manuscript, its originality is an important consideration. Authors need to be aware that all papers in reputable journals are screened to detect overlap with other sources of text and duplication with previously considered papers. If excessive levels of overlap with other texts are detected, then a manuscript will be automatically rejected if the paper is not authored by any of the current authors. If there is overlap with previous papers of the author(s) in areas like the methods this can be reduced by referring to previous papers provided they clearly give all the required detail. This aspect is related to the fact that editors want papers that will advance the knowledge in the area under consideration and not papers that repeat previous work without providing new insights. Methods need to be adequately described and, if animals are involved, approval from an Animal Ethics committee is mandatory for all credible journals. There is a difference between good research and good communication of research, i.e. a well written article cannot make 
up for poor research, whereas a badly written article can diminish good research. For this reason, the flow of a paper is important. Authors should get others to read their papers to give a "fresh" perspective on its readability and flow. If you want editors to reject your paper without review, then submit poorly written papers that are full of mistakes and have poor grammar! An easy first step, that is frequently missed, is to run a spelling- or grammar-check of the manuscript prior to its submission. This is a major consideration for non-English speaking authors, with the major journals printed in English. In this case, my advice is to seek to develop relationships with those who are English speaking.

\section{Paper structure}

The first thing an author should do before writing a paper is to consult the author guidelines for the target journal. For Meat Science we see many papers that fall outside the scope of the journal so you would not submit a paper with a title such as "The effect of dietary betaine on the meat quality, postmortem glycolysis and antioxidant capacity of partridge shank broiler chicken", because the journal does NOT publish papers on poultry meat! Further the formatting of the journal should be followed. You must remember that all editors and reviewers HATE wasting time on poorly prepared manuscripts and will reject them.

The structure of scientific papers is in many ways straight forward, but there are factors to consider for each element of a paper. The title is designed to succinctly indicate to readers what the paper is about, and it needs to be specific, concise, and not full of jargon and abbreviations. Importantly, the content of the paper must match the title. In some cases, authors have submitted papers with titles that do not match the content of the paper, and what the title says and what they did are inconsistent. Following the title, the abstract is the section that promotes the paper and in a succinct way describes the work undertaken and the major findings. If your article is published, the abstract could be the only part that is freely available to users and as such, a clear abstract will strongly influence whether your work is further considered. Connected with this are the key words - these are important because they will be used by search engines, so do not be too narrow, do not repeat words in the title and avoid abbreviations.

The introduction to a paper must contain three elements 1) an overall picture of the issue to be covered, 2) the current state of knowledge and 3) outline what the issue is and what the objective or hypothesis is that you are testing. For the materials and methods (M\&M), include detailed information so that a knowledgeable reader can reproduce the experiment, but use references and supplementary materials to indicate previously published procedures. On this latter point, please reference the primary source that describes the method. Frequently authors will reference secondary sources resulting in a chain of references that must be followed to identify the primary source (if there is one at all!). Ensure there is a section that clearly outlines the design, with the number of samples tested and how replication was applied. The last section of the M\&M should be a section that outlines the statistical analysis and including a sentence to the effect of 'we applied an ANOVA to the data' is just not sufficient, as outlined above.

When outlining the results, these should be presented in a logical way following the order of the $M \& M$, are summarised using tables and figures and focus on the major findings which relate to the objective of the work. Some journals allow results and discussion to be intermingled, but my preference is to keep them separate as it helps the reader in my view to, more easily grasp the findings of the work.

The discussion is the section of the paper that relates the results of the experiment to the aims of the experiment. It does this in the context of what other studies have found, and without avoiding those who may have reported different findings to your own. Again, logical order is important. For example, if the paper covered the growth and carcase characteristics of a livestock species and the meat quality traits, then the results will be discussed in this order. This does not preclude discussion about how, for example, growth rate impacts on meat quality traits, but this would be integrated into the latter aspect. The notable findings should also be the heart of the discussion. There can be a tendency for authors to develop discussion on tangential findings, and this must be kept in check, because it is the hypotheses raised that must be addressed. A good discussion will also outline any identified limitations of the work and SHOULD not extend beyond the limits of the experiment and the data.

The conclusions in a paper must briefly cover the main findings of the work, put the results in context for the current state of knowledge and point the reader to the possible applications of the findings, which could include the need for further work. In this case try to be specific instead of including motherhood statements! 
There are two important remaining components to a paper - the Acknowledgements and the References. For the former, ensure you thank all those who have helped with the work and how they have helped e.g. "Mr Right from Banks Farm is thanked for providing access to his land or Mr Right from the University of Australia is thanked for his technical work in assaying the meat samples for fatty acids". The other important acknowledgement should be to those who provided the funding for the work. Compiling the reference list takes care, with authors needing to ensure the format complies with the journal guidelines. Editors easily detect authors who have submitted a paper that has been rejected elsewhere as often authors fail to check on the in-text referencing and reference list requirements before submitting to another journal! It is very important that authors cite the core papers related to their work and not inflate the reference list. An experimental paper is normally expected to have 25-30 references. On this note, an author should avoid excessive self-citation and not quote every paper they have ever written!

\section{Paper revision}

If your paper makes it past the editor and is sent for review, pending a favorable outcome you will be asked to revise the paper. You should carefully study the reviewer's comments and amend the manuscript accordingly. You MUST respond to all comments even if you disagree with the reviewer. In this instance, provide a scientifically solid rebuttal, but do not ignore the comments. It can be useful to remember that there is a person at both ends of the reviewing process, and reviewer comments are, for the most part, given to be constructive rather than confrontational. With this in mind, avoid being dismissive or aggressive in your responses. When making changes to the manuscript I prefer these to be shown in colored font not as 'track changes', but different journals and editors will have other requirements. Aligned with the changes to the manuscript, a detailed response to the reviewer comments must be provided, and again, I prefer to see each point from the reviewer followed by a response from the author(s) in colored font. This approach makes it easier for editors to assess the responses and the changes, and making it easier for editors should be an objective if you want prompt feedback! The response comments do not have to be extensive; this is dependent on the point raised by the reviewer and for many straightforward changes all that is needed is to say "Amend$e d$ " and give the line number. In other cases, there will be a requirement for a detailed response.

There will be times that the review process has rendered a reject decision for your paper. You must remember this happens to all people, despite their experience and the number of papers they have published. After taking a breath, try to understand why the paper has been rejected and decide if you can revise and address the comments and resubmit the paper. The other possibility is that you need to generate further data, or some re-analysis of the current data is required depending on what the comments were. Authors should note that rejected papers resubmitted to the same journal will now, for many journals, be identified as duplicates and this flags to editors that they need to take a close look to ensure the revised paper has dealt with all the previous comments. Whatever the decision DO NOT submit the paper to the same journal or elsewhere without addressing the reasons for rejection. As an editor I have had authors resubmit the paper without any revisions after a rejection and this is simply not acceptable, and in some cases this is unethical. Plus - your submission could end up with the same reviewer as previously, to the detriment of your reputation and reduce the likelihood of publication.

\section{Further help}

If you have questions or are not clear about something in the publication process, you can always email the editor for the target journal. Additionally, I run seminars/webinars for staff and students on how to publish with some practical exercises to teach about correct experimental design. This can also include how to write a review paper. Contact me if you wish to take up this option. See also https://www.researchgate.net/profile/David-Hopkins-3 


\title{
Kako povećati svoje šanse za objavljivanje naučnog rada
}

\author{
Dejvid L. Hopkins
}

A p s tr a kt: Od svakog naučnika se traži da objavi svoj rad, što je proces koji daje kredibilitet njihovim rezultatima i pruža platformu za primenu tih rezultata u stvarnom životu. Iako je izvođenje eksperimenata srž naučnog rada, nažalost postoji procenat studija koje su zasnovane na pogrešnim oglednim dizajnima ili su ih napisali autori koji ne razumeju kako da robusno analiziraju podatke koji se na taj način generišu. Posledica toga je da kada pokušaju da objave u renomiranim časopisima, njihovi radovi često budu odbijeni. U drugim slučajevima, autori možda ne uzimaju u obzir obim ciljnog časopisa, njihovi radovi su loše napisani ili nisu formatirani u skladu sa smernicama časopisa. Ovo opet dovodi do odbijanja. Sve u svemu, ovo predstavlja veliki trošak za istraživački i razvojni sektor (R\&D), jer neki radovi nikada neće biti objavljeni, pa stoga investicija nije donela nikakav povraćaj. Pored toga, vreme utrošeno na reviziju dokumenata doprinosi ukupnim troškovima preduzimanja samog istraživanja i razvoja. U mnogim slučajevima, bolja obuka može pomoći u smanjenju ovih troškova i značajno poboljšati naučne rezultate naučnika. Ovaj rad je osmišljen da pomogne autorima da poboljšaju svoju stopu uspešnosti kada pokušavaju da objave.

Ključne reči: naučni časopis, objavljivanje, šansa.

Disclosure statement: No potential conflict of interest was reported by authors.

\section{References}

Biffin, T. E., Smith, M. A., Bush, R. D., Morris, S. \& Hopkins, D. L. 2020. The effect of whole carcase medium voltage electrical stimulation, tenderstretching and longissimus infusion with actinidin on alpaca quality Meat Science, 164, Article 108107, https://doi.org/10.1016/j.meatsci.2020.108107
Starkey, C. P., Geesink, G. H., van de Ven, R. J. \& Hopkins, D. L. 2017. The relationship between shear force, compression, collagen characteristics, desmin degradation and sarcomere length in lamb biceps femoris. Meat Science, $12618-21$

Paper received: June $26^{\text {th }} 2021$.

Paper accepted: July $2^{\text {nd }} 2021$. 